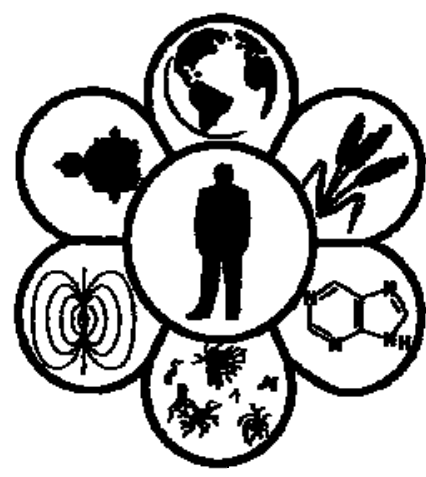

Вісник Дніпропетровського університету. Біологія, медицина Vìsnik Dnìpropetrovs'kogo unìversitetu. Serîa Bìologîâ, medicina

Visnyk of Dnipropetrovsk University. Biology, medicine

Vìsn. Dnìpropetr. Unìv. Ser. Bìol. Med. 2015. 6(2), 103-107.

doi:10.15421/021519

ISSN 2310-4155 print

ISSN 2312-7295 online

www.medicine.dp.ua

UDC 577+589.1+51.082

\title{
Protective/detoxicative function of metallothionein in the rat brain and blood induced by controlled cadmium doses
}

\author{
H.N. Shiyntum, G.A. Ushakova \\ Oles Honchar Dnipropetrovsk National University, Dnipropetrovsk, Ukraine
}

\begin{abstract}
Cadmium classified as a major carcinogen is considered a poisonous and unwanted heavy metal to a lot of tissues in many organisms. Of many publications already available, the general consensus is that the cadmium attenuating element is metallothionein (MT) through its interchangeable mechanism with $\mathrm{Zn}$ triggered by the presence of $\mathrm{Cd}$, providing binding sites for Cd ions. MT was first discovered in the kidney cortex of the horse; it represents a low molecular weight protein, rich in cysteine residues which effectively bind with metals. Its functions consist in detoxification of heavy metals like mercury, arsenic, cadmium, homeostasis of essential metals including copper and zinc, anti-oxidation against reactive oxygen species, protection against DNA damage, oxidative stress, cell survival, angiogenesis, apoptosis, and increase of proliferation. In this work, we sought to highlight the protective function of MT in the brain and serum of rats by means of detoxification under induced effects of controlled Cd doses. We have done this by exposing Wistar rats to Cd at different doses in drinking water at different time intervals. In two independent experiments, 58 rats were subjected to 0.1 or $1.0 \mu \mathrm{g} \mathrm{Cd}^{2+} / \mathrm{kg}$ of body weight for 15 or 36 days under different conditions. The obtained data indicates the different functioning systems for the brain and the blood for MT metabolism under $\mathrm{Cd}$ effect. Our results indicate significant loss of metallothionein level in the brain and important increases in the amount of MT in serum proving that even minimal ingestion of toxic Cd is enough to trigger the release of MT protein in blood.
\end{abstract}

Keywords: protein; brain; blood; metallothionein; cadmium

\section{Защитные/детоксикационные функции металлотионеинов в мозге и крови крыс при действии кадмия в контролированной дозе}

\author{
О.Н. Шийнтум, Г.А. Ушакова
}

\section{Днепропетровский наџиональный университет имени Олеся Гончара, Днепропетровск, Украина}

Согласно современной классификации канцерогенов кадмий считается одним из самых ядовитых и нежелательных тяжелых металлов для многих тканей большинства организмов. Доказана лидирующая роль металлотионеинов как защитных белков в плане ингибирования действия кадмия за счет уникального механизма конкурентного связывания ионов цинка (Zn) в результате наличия ионов Cd за счет реципрокного связывания ионов. МТ был впервые обнаружен в почках лошади и охарактеризован как низкомолекулярный белок, обогащенный остатками цистеина, которые эффективно связываются с металлами. Главная функция данных белков рассматривается в плане детоксикации тяжелых металлов, таких как ртуть, мышьяк и кадмий, а также поддержания гомеостаза внутриклеточных металлов, включая медь и цинк. Металлотионеины также выполняют защитные функции в плане обезвреживания реактивных форм кислорода, защиты от повреждения ДНК, окислительного стресса, активно принимая участие в механизмах регуляции выживания клетки, ангиогенеза, апоптоза и пролиферации клеток. В этой работе мы стремились подчеркнуть защитную функцию металлотионеинов в мозге и крови крыс при индуцировании контролируемых доз Сd. Эксперимент проведен на крысах линии Вистар, которые получали строго контролируемую дозу $\mathrm{Cd}$ с питьевой водой в течение 15 и 36 дней. В ходе двух независимых экспериментов 58 крыс подвергались интоксикации кадмием в дозе 0,1 или 1,0 мкг $\mathrm{Cd}^{2+} /$ кг массы тела каждый день в течение 36 суток. Полученные результаты указывают на специфичность продукции металлотионеинов в мозге и крови исследуемых животных в зависимости от дозы $\mathrm{Cd}$ и времени аккумуляции. Отмечена особенность регуляции продукции металлотионеинов в мозге и крови в ходе хронической аккумуляции кадмия. Полученные данные свидетельствуют о том, что даже минимальная доза 0,1 мкг/кг тела один раз в день в течение 15 суток приводит к стимуляции продукции МТ в крови, при этом отмечается истощение пула МТ в мозге, начиная с 15-го дня аккумуляции. В случае большей хронизации накопления кадмия

Oles Honchar Dnipropetrovsk National University, Gagarin Ave., 72, Dnipropetrovsk, 49010, Ukraine Днепропетровский национальный университет имени Олеся Гончара, Днепропетровск, Украина Tel.:+38-066-309-13-86.E-mail:hnkafor@yahoo.com 
наблюдается еще большее снижение уровня маталлотионеинов в мозге. Хотя ранее была показана индукция синтеза данных белков как первичный ответ на интоксикацию в мозге.

Ключевые слова: белок; мозг; кровь; металлотионеин; кадмий

\section{Introduction}

$\mathrm{Cd}$ is one of the most toxic heavy metals and its toxicity has been widely investigated and reported. This metal is a serious environmental and occupational contaminant and may cause a severe hazard to the health of man and animals (Wang et al., 2014; Kar et al., 2015). Most of the harmful effects of heavy metals on human health are mediated through oxidative stress (Kar et al., 2015). Cadmium has been shown to increase lipid peroxidation and decrease antioxidant reserve of cells, cadmium ions activate lipid peroxidation causing increased loss of antioxidant capacity in response to formation of free radicals. It is important that cadmium salts are classified as "thiol poisons" which block the sulfhydryl group of proteins including enzymes-antioxidants, inhibiting their antioxidant effects (Wang et al., 2014). In addition, $\mathrm{Cd}$ exposure also results in pathological conditions in liver, testis, brain, and nervous system, kidney, spleen, and bone marrow; cadmium exposure may lead to apoptosis in testes of rat, mouse liver, and human T-cells and also appears to inhibit microtubule sliding in bovine sperm axoneme (Wang et al., 2014).

Metallothioneins have been found to exist in numerous organisms ranging from mammals to eukaryotes and some prokaryotes (Babula et al., 2014; Vasak, 2005). The human body expresses at least ten known very closely related MT proteins. The production of MT is zinc and selenium is dependent on dietary minerals as well as histidine and cysteine present in the body. They are largely synthesized in the liver and kidney in humans but are found at a number of other sites. The presence of cysteine in metallothionein is necessary for its functioning and $\mathrm{Cd}$ can be bound to these proteins for up to a month (Higashimoto et al., 2009). MTs are classified based on the similarities of their structures. All mammalian MTs are placed in Class I. The amino acids sequences of MTs of mammalian origin contain approximately 61 amino acids of similar composition. They all contain 20 cysteine residues that remain unchanged along the polypeptide sequence. These cysteines participate in the coordination of $7 \mathrm{~mol}$ of $\mathrm{Cd}$ or $\mathrm{Zn}$ per mol of MT, explaining why they feature high affinity for $\mathrm{Cd}\left(10^{-22}\right)$ and $\mathrm{Zn}\left(10^{-18}\right)$. MTs are involved in the homeostatic regulation of metals which provides a reservoir of metals for other metalloproteins or metallo- enzymes, in heavy metal detoxification, in protection of tissues against various forms of oxidative injuries and transferring of essential metals (Coyle et al., 2002; Baird et al., 2006). Qu and Waalkes (2013) demonstrated that MTcompetent cells activate MT in response to $\mathrm{Cd}$, while MTdeficient cells adapt to $\mathrm{Cd}$ primarily by turning on oxidant response systems.

Like the brain, blood is absolutely vital for any mammal's system and since it flows through every major vein associated with every organ of the body, its purity is a priority as any infection is destined to affect the rest of the body. There are numerous manuscripts proving MT functioning in different organs and other parts of the body (Kar et al., 2015; Nair et al., 2013, Yang and Shu, 2015, Braga et al., 2015,
Shiyntum and Ushakova, 2015) and in blood serum related to Cd (Kowalska et al., 2015) also suggesting it detoxifies the plasma. An increase in serum MT has also been registered with human serum under poisoning by other heavy metals (Petrlová et al., 2005).

We strived in this work to show the protective function of MT induced by the presence of controlled doses of $\mathrm{Cd}$ in the brain and blood of rats.

\section{Materials and Methods}

The experiment was carried out in two steps. In the first step, 18 Wistar rats, aged 20-26 weeks, weighing 150-200 g were subjected to poisoning with $\mathrm{Cd}$ at different dose levels for 36 days. 18 rats were divided into 3 groups of 6 rats each: group I was exposed to standard conditions with a standard diet, group II rats were exposed to $\mathrm{Cd}$ at a dose of $0.1 \mu \mathrm{g} / \mathrm{kg}$ of body weight, and $1.0 \mu \mathrm{g} / \mathrm{kg}$ of body weight of $\mathrm{Cd}$ was administered to group 3 rats. The administration of $\mathrm{Cd}$ to the experimental groups was carried out intragastrically through a sterile stainless steel probe integrated with adjustable dispenser. Two doses were prepared from High-purified $\mathrm{CdCl}_{2} \cdot 2.5 \mathrm{H}_{2} \mathrm{O}$ (Sigma, USA) with pure deionized water "Malyatko" (Econiya, Ukraine) and administered daily. Control animals received the same volume of water. The animals were weighed prior to each cadmium solution introduction. The volume of the solution was calculated on the basis of the dose under study. The rats were maintained under standard conditions with natural day/night cycle receiving standard diet. Water and food were freely available. The experiment lasted 36 days and was performed accordingly to "Provisions for the use of animals in biomedical experiments" (Medical ethics and human rights: Provisions on the use of animals in biomedical experiments, 2003). For the next experiment 40 Wistar rats were subjected to different doses of Cd under different conditions at different time intervals as indicated below:

1) under controlled experiment with pure water for 15 days;

2) exposed to $0.1 \mu \mathrm{g} \mathrm{Cd}^{2+} / \mathrm{kg}$ of body weight for 15 days;

3) $1.0 \mu \mathrm{g} \mathrm{Cd}^{2+} / \mathrm{kg}$ of body weight for 15 days;

4) under controlled experiment with pure water for 36 days;

5) $0.1 \mu \mathrm{g} \mathrm{Cd}^{2+} / \mathrm{kg}$ of body weight for 36 days;

6) $1.0 \mu \mathrm{g} \mathrm{Cd}^{2+} / \mathrm{kg}$ of body weight for 36 days;

7) $0.1 \mu \mathrm{g} \mathrm{Cd}^{2+} / \mathrm{kg}$ of body weight for 35 days $+1.0 \mu \mathrm{g}$ $\mathrm{Cd}^{2+} / \mathrm{kg}$ of body weight on day 36 ;

8) $1.0 \mu \mathrm{g} \mathrm{Cd}^{2+} / \mathrm{kg}$ of body weight for 35 days $+10.0 \mu \mathrm{g}$ $\mathrm{Cd}^{2+} / \mathrm{kg}$ of body weight on day 36 .

At the end of the experiment, the animals were decapitated under mild anesthesia (isofluran) and cerebellum, and their hippocampus and thalamus were isolated. In order to study MT function induced by $\mathrm{Cd}$, soluble cytosolic protein fractions of these brain parts and blood were obtained by homogenization and differential centrifugation at $20000 \mathrm{~g}$ per $60 \mathrm{~min}$. The initial buffer contained Tris $0.25 \mathrm{mM}$ (pH 7,4) ethylenediaminetetraacetate (EDTA) $1.0 \mathrm{mM}$, dithiothreitol $2.0 \mathrm{mM}$, phenylmethylsulfonyl fluoride (PMSF) $0.2 \mathrm{mM}$, sodium azide $\left(\mathrm{NaN}_{3}\right) 3 \mathrm{mM}$ (all indicated reagents 
from Sigma, USA). The level of MT in obtained brain extracts and blood serum was measured by competitive ELISA using polyclonal antibody to MT (Santa Cruz, USA), and pured MT as a standard (Sigma, USA). Blood serum was extracted according to the standard protocol (blood incubation at room temperature for $30 \mathrm{~min}$ and centrifugation at $12000 \mathrm{~g}$ for $10 \mathrm{~min}$ ). Statistical analysis of the results was performed using SPSS 10.0 for Windows, the difference was considered significant at $\mathrm{P}<0.05$.

\section{Results and Discussion}

Expression of MTs is induced by many factors including physical stress, chemical stress and endogenous factors. Induction of MTs in relation to heavy metals, important environment pollutants, has been demonstrated in many tissues including liver, kidney, intestine or pancreas - (Petr et al., 2012). Due to the abundant thiol groups in their cysteine residues, having high affinity to metal ions, MTs are thought to play an important role not only in the homeostasis of physiological metal ions, such as zinc, copper, and selenium, but also in protection from the toxicity of heavy metals, such as cadmium, mercury, lead, and arsenic (Yang and Shu,
2015). In our recent publications we proved that presence of $0.1 \mu \mathrm{g}$ of $\mathrm{Cd}^{2+}$ was enough to induce the secretion of MT (Shiyntum and Ushakova, 2015) and increase in the total protein amount in the brain (Kovalchuk et al., 2015, Shiyntum and Ushakova, 2015). In this present work, we compared this inductive effect of $\mathrm{Cd}^{2+}$ under different experimental doses in the brain and in blood in an attempt to demonstrate the protective function of MT against $\mathrm{Cd}$ and we came out with the results illustrated below.

In case of the brain, there is a sharp fall in the amount of MT in both the cerebellum and the hippocampus and a less significant decrease in the thalamus after 36 days of poisoning (Fig. 1). Deducing from the figure above, we realized the differences in MT presence percentages of $82.2 \%$ for $0.1 \mu \mathrm{g} \mathrm{Cd}^{2+}$ and $74.2 \%$ for $1.0 \mu \mathrm{g} \mathrm{Cd}^{2+}$ from $100 \%$ control in case of the cerebellum, $72.0 \%$ for $0.1 \mu \mathrm{g} \mathrm{Cd}^{2+}$ and $58.1 \%$ for $1.0 \mu \mathrm{g} \mathrm{Cd}^{2+}$ for hippocampus, and $93.4 \%$ per $0.1 \mu \mathrm{g} \mathrm{Cd}^{2+}$ and $82.7 \%$ per $1.0 \mu \mathrm{g} \mathrm{Cd}^{2+}$ for thalamus. Although the decrease in the thalamus is less significant, it still proves that $\mathrm{Cd}$ is a strong inducer of MT gene (Françoise et al., 2014) as in the other two cases. The decrease in MT is certainly due to the protective function which entails redistribution to other organs (Yang and Shu, 2015) occurring only after 36-day period.

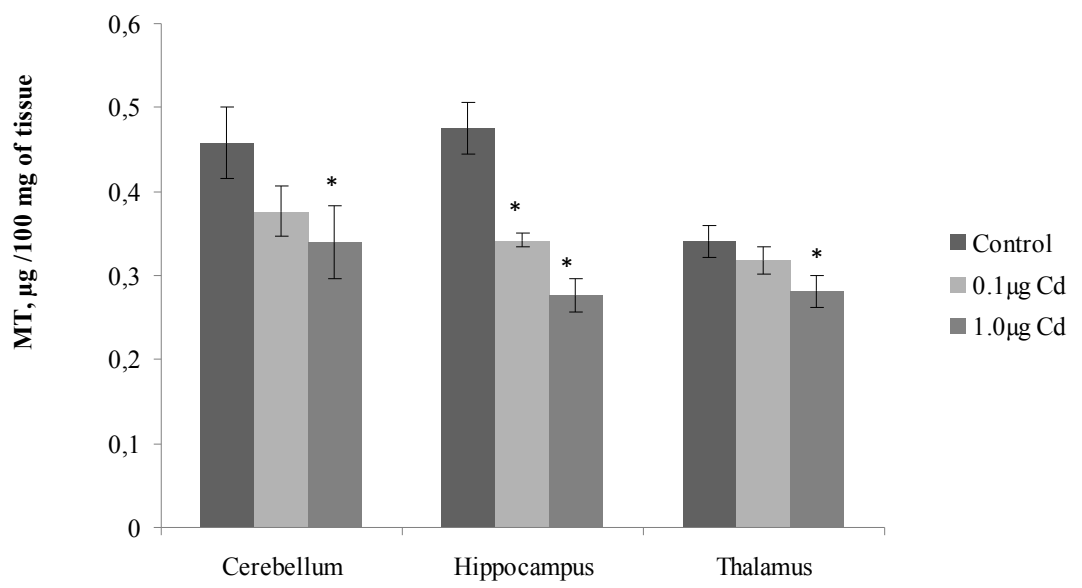

Fig. 1. MT levels in the brain under $\mathrm{Cd}$ controlled doses introduced intragastrically for 36 days: * $-\mathrm{P}<0.05 ; \mathrm{n}=6$

Cadmium-metallothionein $(\mathrm{Cd}-\mathrm{MT})$ is then released to the circulation system; due to small size of MTs, the complex is easily filtered through the glomerulus and reabsorbed by the proximal tubular (PT) epithelial cells via endocytosis (Dudley et al., 1985; Zalups and Ahmad, 2003). With major increases in MT levels after the first few days, this result implies that the longer the presence of $\mathrm{Cd}$ in the brain, the less MT we have present in the brain. This confirms the function of MT as heavy metal detoxifying and protective agent. Expression analyses based on RT-PCR experiments show that, as for MT1 and MT-2, human MT-3 is also ubiquitously expressed while MT-4 transcripts are present in brain, testes, esophagus and mainly in thymus (Moleirinho et al., 2011).

The data obtained in our experiment indicates dosedependent effect of cadmium on the content of MT in the rat brain. Furthermore, the specificity of this effect is determined by the peculiarities of different parts of the brain that affect the functional properties of the respective brain parts and the central nervous system as a whole. According to our results, we can see that hippocampus is more sensitive brain structure to the cadmium intoxication compared to the cerebellum and thalamus. Fig. 2 and 3 show different effects of varying $\mathrm{Cd}$ doses on MT in blood serum. It explicitly shows the rise in the levels of MT in serum under the administration of Cd. In Fig. 2, there is an increase in MT levels by $131 \%$ and $128 \%$ under 0.1 and $1.0 \mu \mathrm{g}$ respectively, showing that the induction of MT is easily triggered even at minimum amounts of $\mathrm{Cd}$.

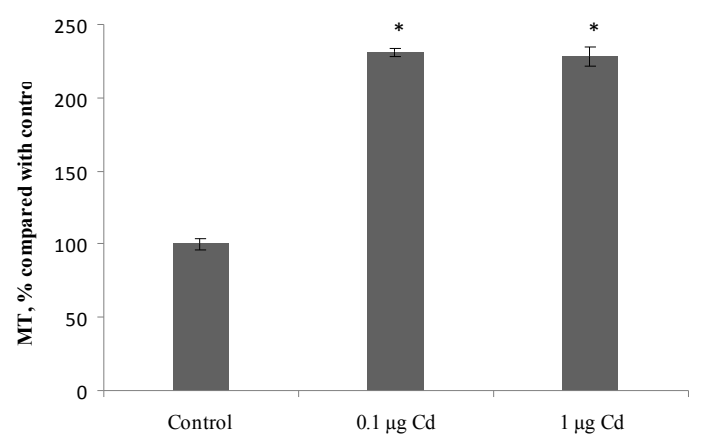

Fig. 2. Cd effect on MT levels in blood serum under 0.1 and $1.0 \mu \mathrm{g}$ administered doses compared to control for 15 days: * $-\mathrm{P}<0.05$ compared to control group; $\mathrm{n}=5$ 
Two concentrations are at the same level because any first $\mathrm{Cd}$ administration almost always causes the same inductive effect. Fig. 3 almost mirrors Fig. 2 to perfection except for the addition of the last two concentrations shown in the last two bars. The spikes in these last two bars of the histogram prove that instant induction of the higher dose than the previously constant dose is capable of causing an increase in MT secretion. In the cases where $1.0 \mu \mathrm{g} \mathrm{Cd}^{2+}$ and $10.0 \mu \mathrm{g}$
$\mathrm{Cd}^{2+}$ were added to rats that were already exposed to $0.1 \mu \mathrm{g}$ $\mathrm{Cd}^{2+}$ and $1.0 \mu \mathrm{g} \mathrm{Cd}^{2+}$ respectively, increase in MT was slightly (191.5\% from $158.5 \%)$ and significantly $(273.7 \%$ from $157.6 \%$ ) noted. Thus, any addition of a new dose of $\mathrm{Cd}$ at any time initially induces high provision of MT which after a while stabilizes and then begins to fall during transportation to other organs.

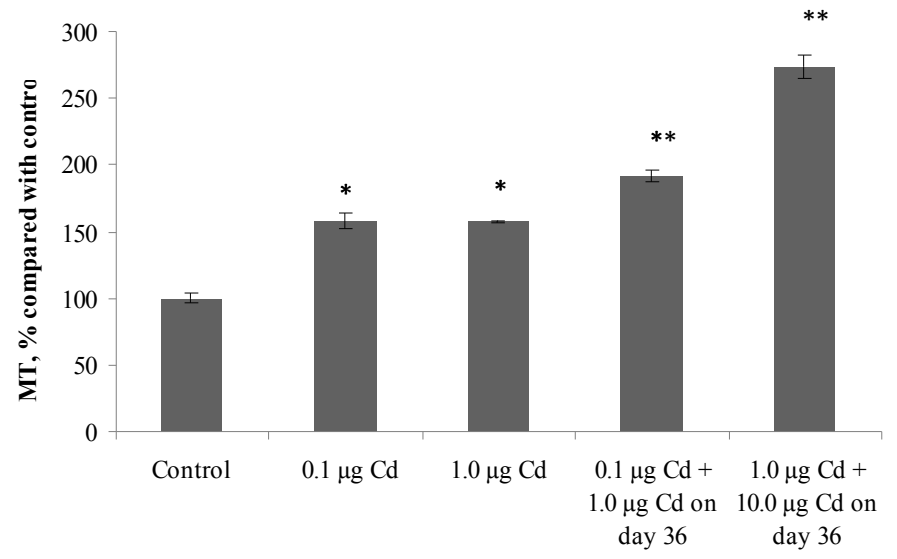

Fig. 3. Cd effect on MT levels in blood serum under administration of varying doses in different conditions for 36 days: ${ }^{*}-\mathrm{P}<0.05$ compared to control group, ${ }^{* *}-\mathrm{P}<0.05$ compared to 2 and 3 groups, respectively; $\mathrm{n}=5$

\section{Conclusion}

The obtained data indicates the different functioning systems for the brain and the blood for MT metabolism under $\mathrm{Cd}$ effect. In the brain, there is a rise in MT levels after the first few days of induction by $\mathrm{Cd}$ but with the longer period of $\mathrm{Cd}$ administration, there is a fall in MT levels enhanced most probably by redistribution of the MT-Cd complex to other organs. Meanwhile in blood there is much more production of MT which accounts for high amounts on days 15 and 36 and even in as small a dose as $0.1 \mu \mathrm{g}$ of cadmium.

\section{Acknowledgement}

We send our thanks to the colleagues from V.N. Karazin Kharkiv National University, Dept. of Biochemistry Prof. E.E. Persky and Dr. Y.G. Kot for their cooperation.

\section{References}

Babula, P., Masarik, M., Adam, V., Eckschlager, T., Stiborova, M., Trnkova, L., Skutkova, H., Provaznik, I., Hubalekadi, J., Kizek, R., 2012. Mammalian metallothioneins: Properties and functions. Metallomics 4, 739-750.

Baird, S.K., Kurz, T., Brunk, U.T., 2006. Metallothionein protects against oxidative stress-induced lysosomal destabilization. Biochem. J. 394, 275-283.

Braga, M.M., Dick, T., de Oliveira, D.L., Scopel-Guerra, A., Mussulini, B.H.M., Souza, D.O., da Rocha., J.B.T., 2015. Evaluation of zinc effect on cadmium action in lipid peroxidation and metallothionein levels in the brain. Toxicology Reports 2, 858-863.

Coyle, P., Philcox, J.C., Carey, L.C., Rofe, A.M., 2002. Metallothionein: The multipurpose protein. Cell Mol. Life Sci. 59(4), 627-647.

Dudley, E.R., Gammal, L.M., Klaassen, C.D., 1985. Cadmiuminduced hepatic and renal injury in chronically exposed rats: Likely role of hepatic cadmium-metallothionein in nephrotoxicity. Toxicol. Appl. Pharmacol. 77, 414-426.
Françoise, V.-H., Amélie, C., Catherine, G.-F., 2014. Metallothionein mRNA induction is correlated with the decrease of DNA strand breaks in cadmium exposed zebra mussels. Mutat. Res.-Gen. Tox. En. 766, 10-15.

Higashimoto, M., Isoyama, N., Ishibashi, S., Inoue, M., Takiguchi, M., Suzuki, S., Onishi, Y., Sato, M., 2009. Tissue dependent preventive effect of metallothionein against DNA damage in dyslipidemic mice under repeated stresses of fasting or restraint. Life Sci. 84, 569-575.

Hogervorst, J., Plusquin, M., Vangronsveld, J., Nawrot, T., Cuypers, A., Van Hecke, E., Roels, H.A., Carleer, R., Staessen, J.A., 2007. House dust as possible route of environmental exposure to cadmium and lead in the adult general population. Environ. Res. 103(1), 30-37.

Kagi, J.H., Valee, B.L., 1960. Metallothionein: A cadmium- and zinc-containing protein from equine renal cortex. J. Biol. Chem. 235, 3460-3465.

Kar, R., Garg, S., Halder, S., Galav, V., Chandra, N., Mehndiratta, M., 2015. Cadmium exposure induces oxidative stress by decreasing expression of antioxidant enzymes in mice liver. Int. J. Clin. Biochem. Res. 2(2), 89-96.

Klaassen, C.D., Liu, J., Diwan, B.A., 2009. Metallothionein protection of cadmium toxicity. Toxicol. Appl. Pharmacol. 238(3), 215-220.

Kovalchuk, Y.P., Ushakova, G.A., Shiyntum, H.N., Kot, Y.G., 2015. Distribution of the contents of S100b protein in different parts of the rat brain under the influence of cadmium. Theoretical and Applied Problems of Modern Science and Education, Kursk, 97-101.

Kowalska, K., Bizon, A., Zalewska, M., Milnerowicz, H., 2015. The influence of biological and environmental factors on metallothionein concentration in the blood. J. Trace Elem. Med. Biol. 29, 99-103.

Moleirinho, A., Carneiro, J., Matthiesen, R., Silva, R.M., Amorim, A., Azevedo, L., 2011. Gains, losses, and changes of function after gene duplication: study of the metallothionein family. PLoS One 6(4), e18487.

Nair, A.R., DeGheselle, O., Smeets, K., van Kerkhove, E., Cuypers, A., 2013. Cadmium-induced pathologies: Where is the oxidative balance lost (or not)? Int. J. Mol. Sci. 14(3), 6116-6143. 
Petrlová, J., Blaštík, O., Průša, R., Kukačka, J., Potěšil, D., Mikelová, R., Adam, V., Zehnálek, J., Kizek, R., 2005. Using of electrochemical methods for studying of metallothionein content in the human blood serum of a patient poisoned by lead and treated by platinum. Biomed. Pap. Med. Fac. Univ. Palacky Olomouc. Czech. Repub. 149(2), 485-488.

Qu, W., Pi, J., Waalkes, M.P., 2013. Metallothionein blocks oxidative DNA damage in vitro. Arch. Toxicol. 87(2), 311-321.

Shiyntum, H.N., Ushakova, G.A., 2015. Distribution of metallothioneins I \& II in the rat brain under Cd-inhalation. Proceedings of First International Workshop "Actual problems of fundamental science", Luck, 334-337.

Vasak, M., 2005. Advances in metallothionein structure and functions. J. Trace Elem. Med. Biol. 19(1), 13-17.
Waalkes, M.P., 2003. Cadmium carcinogenesis. Mutat. Res. 533(1-2), 107-120.

Wang, J., Zhu, H., Liu, X., Liu, Z., 2014. N-acetylcysteine protects against cadmium-induced oxidative stress in rat hepatocytes. J. Vet. Sci. 15(4), 485-493.

Wang, W.-C., Mao, H., Ma, D.-D., Yang, W.-X., 2014. Characteristics, functions, and applications of metallothionein in aquatic vertebrates. Front. Mar. Sci. 1, 34.

Yang, H., Shu, Y., 2015. Cadmium transporters in the kidney and cadmium-induced nephrotoxicity. Int. J. Mol. Sci. 16(1), 1484-1494.

Zalups, R.K., Ahmad, S., 2003. Molecular handling of cadmium in transporting epithelia. Toxicol. Appl. Pharmacol. 186(3), 163-188.

Надійшла до редколегії 15.09.2015 